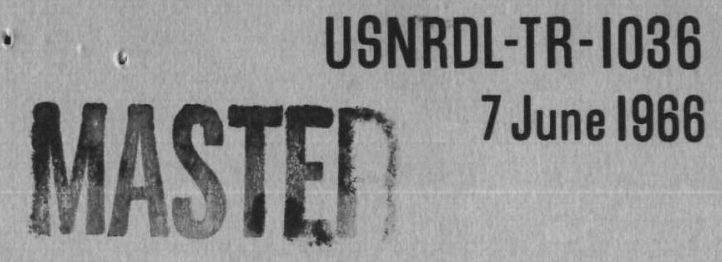

CrSTI RNEES

\title{
ELECTROCHEMICAL CORROSION STUDIES OF SNAP CONTAINER MATERIALS \\ $\mathrm{BH}, \mathrm{c}, 1.00 ; \mathrm{mN} .50$
}

by
D.A. Kubose
H.I. Cordova

U.S. NAVALA R D IOLOGICA L

D E F E N S E L A B O R A T O R Y

SAN FRANCISCO- CALIFORNIA.94135 


\section{DISCLAIMER}

This report was prepared as an account of work sponsored by an agency of the United States Government. Neither the United States Government nor any agency Thereof, nor any of their employees, makes any warranty, express or implied, or assumes any legal liability or responsibility for the accuracy, completeness, or usefulness of any information, apparatus, product, or process disclosed, or represents that its use would not infringe privately owned rights. Reference herein to any specific commercial product, process, or service by trade name, trademark, manufacturer, or otherwise does not necessarily constitute or imply its endorsement, recommendation, or favoring by the United States Government or any agency thereof. The views and opinions of authors expressed herein do not necessarily state or reflect those of the United States Government or any agency thereof. 


\section{DISCLAIMER}

Portions of this document may be illegible in electronic image products. Images are produced from the best available original document. 
APPLIED RESEARCH BRANCH

D. L. Love, Head

CHEMICAL TECHNOLOGY DTVISION

R. Cole, Head

\section{ADMINISTRATIVE INFORMATION}

The work reported was part of a project sponsored by the Atomic Energy Commission under Contract No. AT(49-5)-2084.

DDC AVAILABILITY NOTICE

Distribution of this document is unlimited.

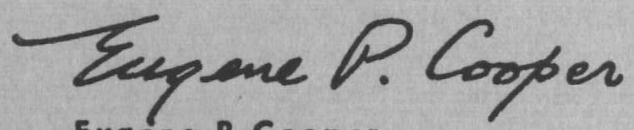




\section{ABSTRACT}

Corrosion rates of Haynes 25, Hastelloy $\mathrm{C}$ and Hastelloy $\mathrm{N}$ in natural seawater were determined by galvanostatic polarization techniques. Values of approximately $10^{-2}$ mils per year were obtained for each of the alloys. No significant effect of aeration and solution stirring on the corrosion rates was observed.

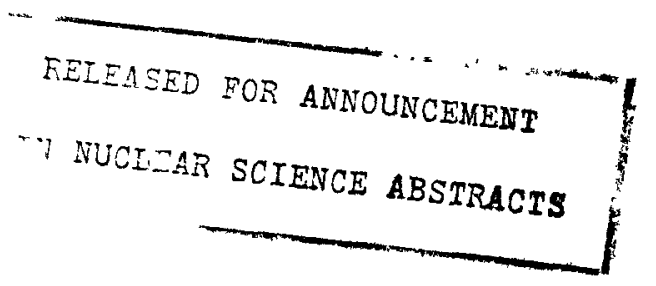


A program to study the release of radionuclides from nuclear power sources to an ocean environment requires knowledge of the corrosion rates in seawater of the material containing the radionuclide. To obtain an initial indication of the corrosion rates of certain container materials, Hastelloy C, Hastelloy N and Haynes25 alloys, electrochemical polarization studies in seawater were conducted on them.

The results indicate that the corrosion rate is of the order of $10^{-2}$ mils per year for all three alloys. No significant effect of aeration, deaeration, and solution stirring on the corrosion rates was observed. 
INIRODUCTION

For several years this laboratory has been investigating the release of radionuclide fuels employed in operational and proposed Systems for Nuclear Auxiliary Power (SNAP) to the seawater environment.

The work was initially concerned with the seawater reactions and solubility rates of fuel forms used in SNAP radionuclide power devices.1,* The program was subsequently broadened to include studies of the release of fission products from irradiated nuclear power reactor fuels to seawater, $2,3,4,{ }^{*}$ and measurement of the corrosion rates in seawater of the material containing the SNAP radionuclides. The container materials considered for this initial corrosion study were Haynes 25, Hastelloy C and Hastelloy $\mathrm{N}$.

Because of the expected low corrosion rates of these alloys, especlally sensitive techniques of corrosion rate measurement were required. The use of three such techniques was instituted: 1) measurement of the concentration of radioactivity leached into the seawater from nuclear reactor-activated alloy specimens, 2) activation analysis of corrosion products in seawater in which inactive alloy specimens have been placed (to determine whether the gamma recoil from the thermal neutron activation of the alloys in the first technique has affected their corrosion properties), and 3) established electro-chemical techniques.

* M.G. Lai and H.A. Goya, "Radionuclide Release From Radionuclide Power Sources. II. Release From Plutonium Metal to Seawater", U.S. Naval Radiological Defense Laboratory, USNRDL-TR- (in preparation).

**L. W. Weisbecker, "Radionuclide Release From Aero-Space Muclear Reactor Fuels. IV. Phase Two: Safeguards Analysis of Pulsed Neutron Irradiation of Fuel in Water", U.S. Naval Radiological Defense laboratory, USNRDL-TR- (in preparation). L. W. Weisbecker, et al., "Radionuclide Release From Aero-Space Nuclear Reactor Fuels. V. Phase Two: Pulsed Neutron Irradiation of Fuel in Water", U.S. Naval Radiological Defense Iaboratory, USNRDL-TR (in preparation). 
The data obtained by these techniques will be compared in a later report. Differences in the experimental conditions will be accounted for in the comparison.

The present report describes a study of the corrosion rates of Haymes 25, Hastelloy $\mathrm{C}$ and Hastelloy $\mathrm{N}$ in seawater using electrochemical techniques only.

\section{BACKGROUND}

Anodic and cathodic polarization of the metal by an externally applied current are the basic electrochemical measurements which provide data for the study of the corrosion behavior of a metal in a corrosive solution. The magnitude of the polarization is expressed in terms of a displacement of the metal electrode potential from its equilibrium (or corrosion) potential by the applied current. This displacement of potential is termed overvoltage. Electrochemical polarization data, in the form of plots of overvoltage versus current, can be obtained in two ways depending on whether the potential or the current is chosen as the independent variable. When potential is the independent variable the term "potentiostatic polarization" applies; when current is the independent variable the term "galvanostatic polarization" applies. The type of polarization used to obtain the present results was galvanostatic.

For low values of applied current, expressed in units of amp $/ \mathrm{cm}^{2}$ of metal electrode surface and referred to as current density, the dominant process controlling polarization is the reaction occurring at the electrode. For values of overvoltage greater than about 50 millivolts the relation between overvoltage and current density in this region is

$$
E=\beta \log i / i_{0}
$$

where $E$ represents the magnitude of polarization in volts (i.e., the overvoltage), $B$ and $i_{0}$ are constants for a given system and $i$ is the applied current density. Equation 1 is referred to as the Tafel equation*, $\beta$ is the Tafel slope when $E$ is plotted against $\log i$, and $i_{0}$ is the exchange current density. At higher values of $i$ the electrode

*Named after J. Tafel who first proposed a similar equation in 1904 to express hydrogen overvoltage as a function of current density. (z. physik. Chem. 50:641 (1904). 
reaction becomes diffusion-controlled, and a plot of $E$ against $\log 1$ becomes non-linear.

Stern and Geary 5,6 have shown that when a system can be described by Eq. I the following relation applies when the overvoltage is less than about 50 millivolts.

$$
\Delta E / \Delta t=\frac{\beta_{a} \beta_{c}}{2.3 i_{\operatorname{corr}}\left(\beta_{a}+\beta_{c}\right)}
$$

where the quantity $\Delta E / \Delta_{i}$ is the slope near the region of the corrosion potential for which the change of $E$ with $i$ is linear, $\beta_{a}$ and $\beta_{c}$ refer to the Tafel slopes for anodic and cathodic polarization, respectively and $i_{\text {corr }}$ is the corrosion current in units of amp/ $\mathrm{cm}^{2}$. This relation is valid for both anodic and cathodic polarization. However, in practice the cathodic polarization curve is used since it is experimentally easier to obtain in the region below 50 millivolts. $1_{\text {corr }}$ is calculated from $E q .1$ and 2 using the experimentally determined values of $\beta_{a}, \beta_{c}$
and $\Delta E / \Delta 1$.

EXPPERTMENTAL

Polarization Equipment

The current was measured by determining the voltage drop across a precision 10 megohm or 1 megohm (for higher values of current) resistance with a Keithley 6IOBR electrometer. The potential of the sample electrode versus a saturated calomel electrode (S.C.E.) was measured with a high-input-impedance John Fluke differential voltmeter, model 803B. The electrometer had a stated accuracy of $+1 \%$ of full scale on all ranges. The voltmeter had a stated accuracy of $\pm 0.05 \%$ of the input voltage from 0.1 to $500 \mathrm{VDC}$ and $+(0.05 \%+50$ microvolts $)$ of the input voltage below 0.1 VDC. The powe $\bar{r}$ supply used was a Trygon Electronics Model S36-5. It had a stated stability of $0.05 \%$ or 18 millivolts over an 8-hour period. A diagram of the circuit used is shown in Fig. 1. 


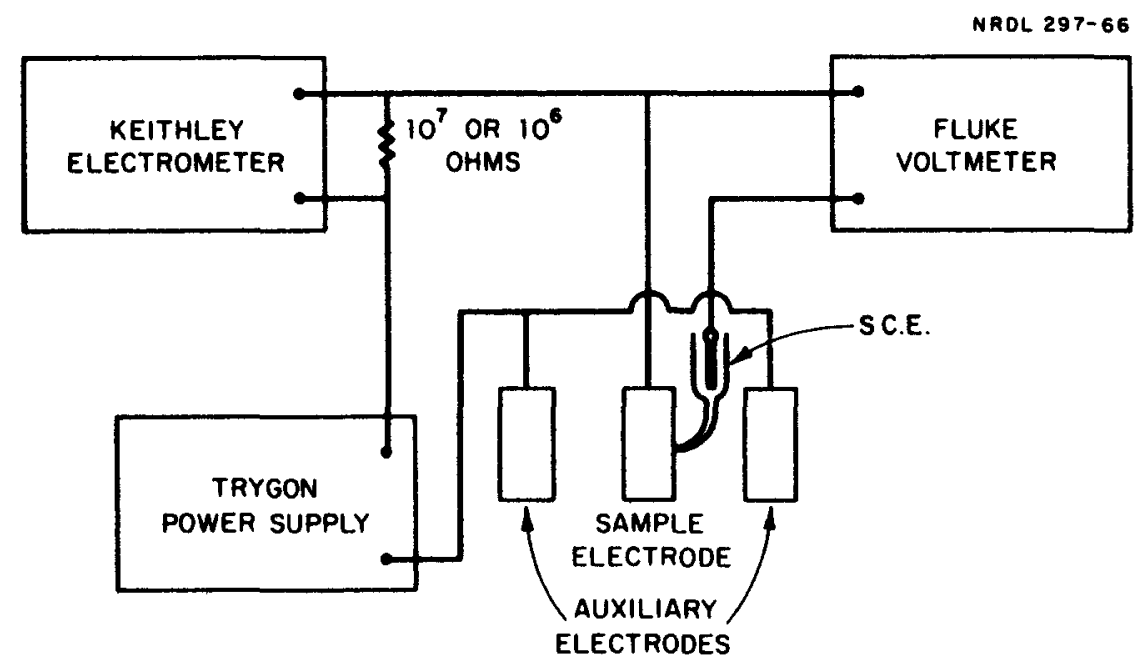

Fig. 1 Galvanostatic polarization circuit. 


\section{Polarization Cell}

The polarization cell was a standard l-liter, 4-neck, round-bottom, pyrex flask modffied by a ball socket on one side to provide access for a Luggin capillary probe and saturated calomel electrode (S.C.E.) assembly. Two Beckmen \# 39271 platinum thimble electrodes were used as the auxiliary electrodes (Fig. 1). Test gases, either nitrogen or air, were introduced into the cell by a fritted pyrex glass bubbler.

The specimens of Haynes 25, Hastelloy $\mathrm{C}$ and Hastelloy $\mathrm{N}$ were fabricated into electrodes from rods obtained from Stellite Division, Union Carbide Co. Table 1 shows the manufacturer's analysis of the alloys. The rods were machined into right circular cylinders 0.5 inches in height and 0.25 inches in diameter. One end was drilled in each cylinder and a tapped stainless steel sleeve inserted for mounting on the electrode assembly, shown in Fig. 2. The complete polarization cell is shown in Fig. 3. In experiments where solution stirring was desired, a magnetic mixer was used.

\section{Seawater}

The seawater used in these experiments was collected near the Farallon Islands, located about 20 miles off the coast of northern Califormia, by a previously described method. ${ }^{2}$ Before use the seawater was filtered through a millipore filter ( 0.8 micron).

PROCEDURE

Each electrode was polished with \#2, \#0 and \#00 emery paper, in that order. After it was mounted on the electrode assembly, the electrode was cleaned in benzene, then in ethanol with the use of an ultrasonic cleaner. After a final rinse in distilled water, the electrode was placed in the polarization cell containing seawater previously saturated with either nitrogen or air. The same gas was kept bubbling through the seawater throughout the experiment.

After the sample electrode had attained a steady state corrosion potential, polarization measurements were conducted by applying current from the power supply in increasing increments at regular time intervals, usually about $5 \mathrm{~min}$. For each current value the corresponding potential of the sample electrode versus S.C.E. was noted. All experiments were conducted at ambient room temperature $\left(\mathrm{Ca} 23^{\circ} \mathrm{C}\right)$. 
TABLE I

Manufacturer's Composition and Analysis of Test Alloys

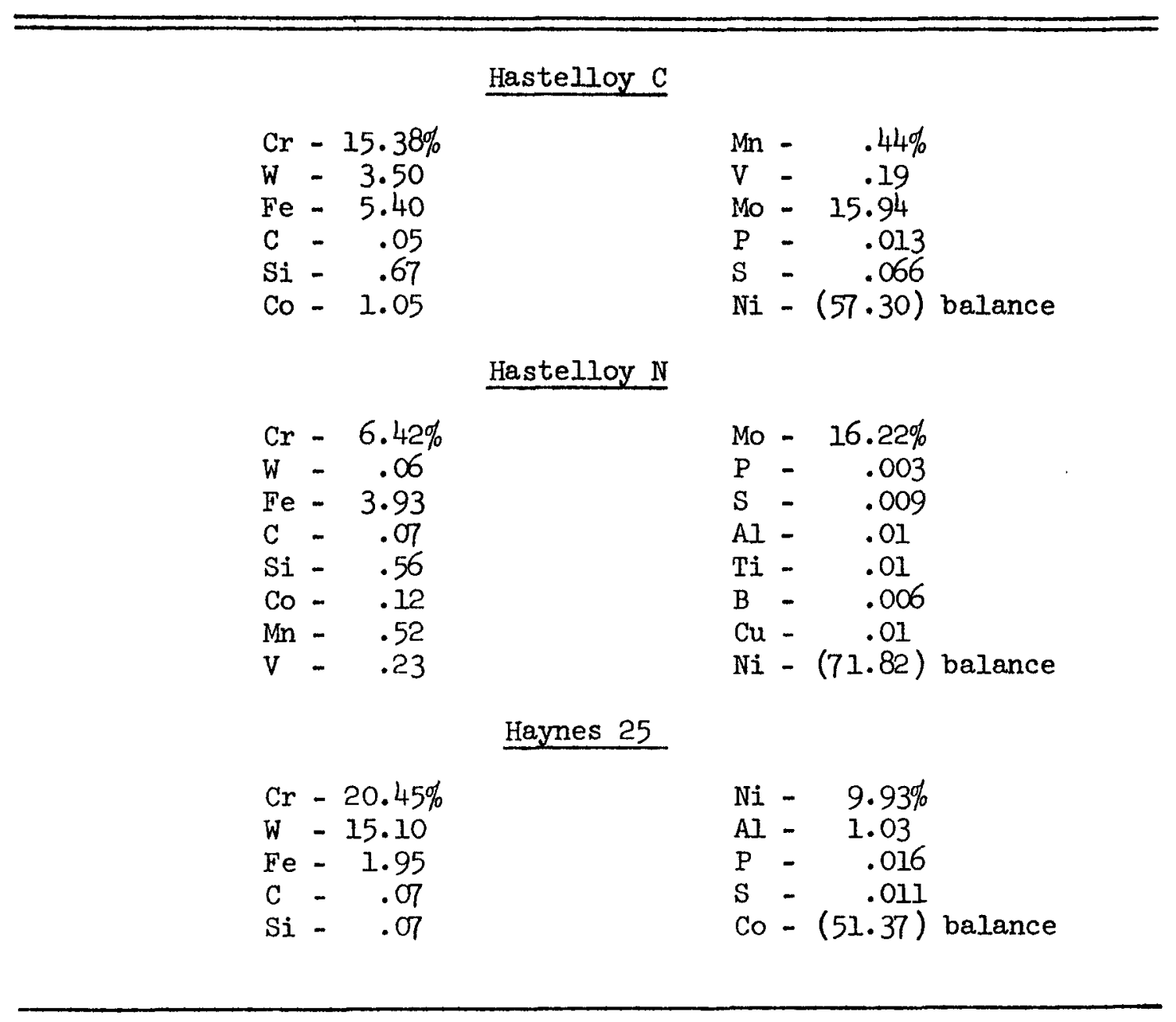




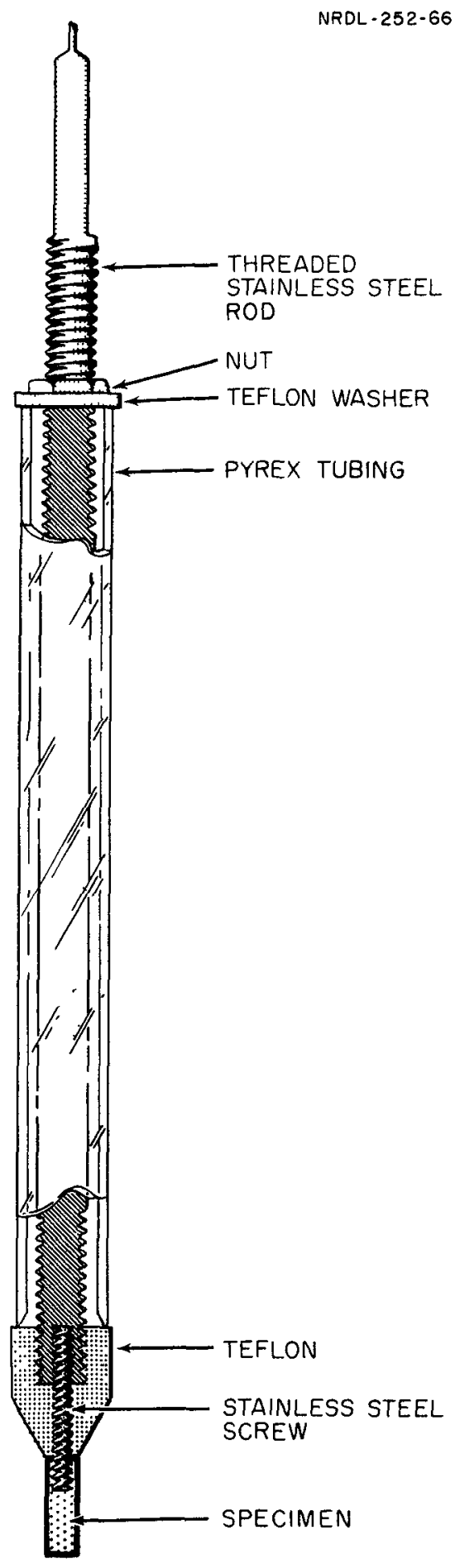

Fig. 2 Specimen electrode assembly. 


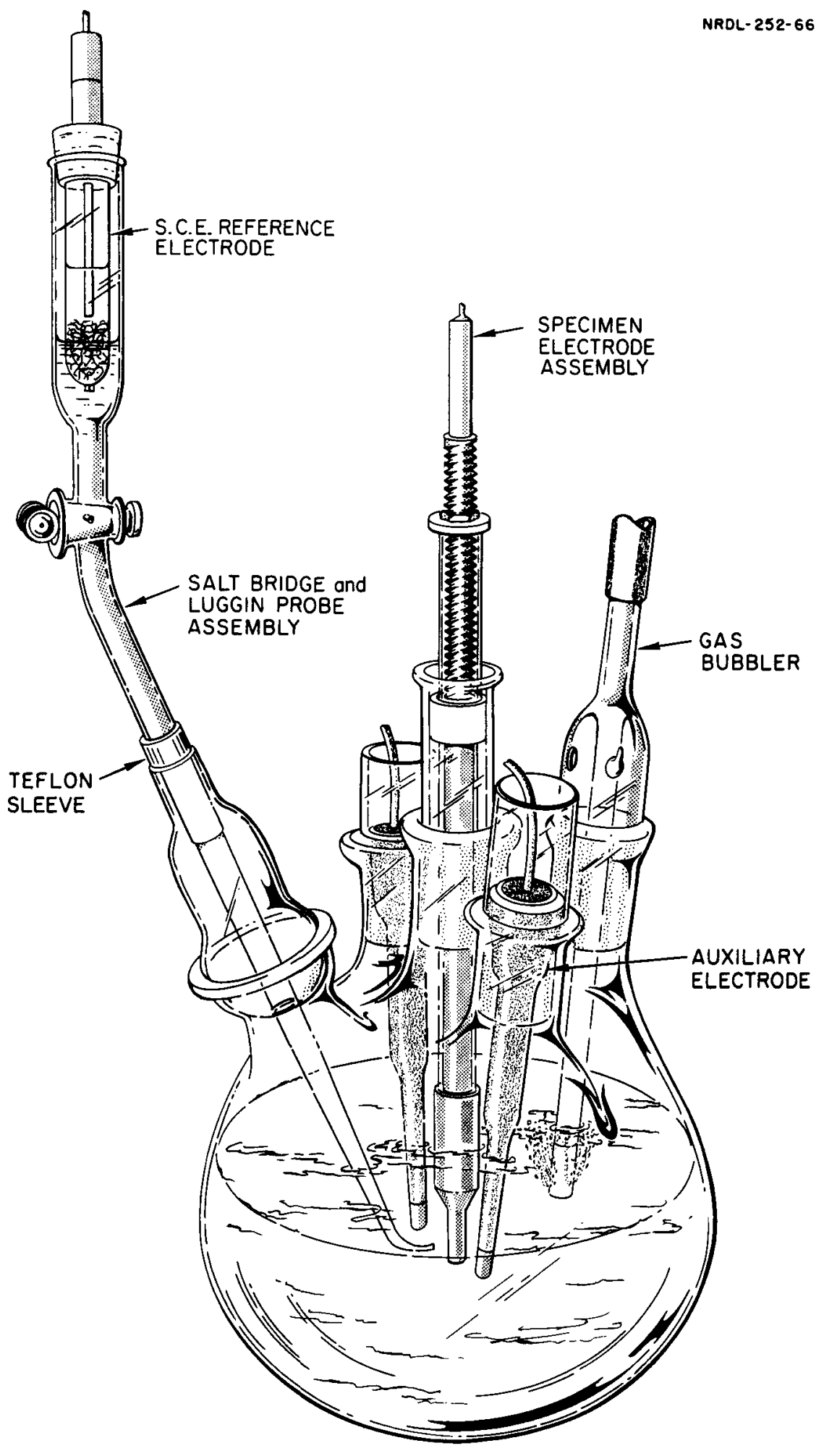

Fig. 3 Polarization cell 
RESULTS AND DISCUSSION

Figures 4 through 11 show the plots of E against log 1 obtained for each of the three alloys under various conditions of aeration, deaeration, and solution stirring. In most instances the Tafel region was not too well-defined and consequently the determination of the Tafel slope by the best straight line was somewhat subjective, even when the points for the higher values of current were neglected. This subjectiveness is not reflected too severely in calculating values of $i_{\text {corr }}$ since the term $\beta_{a} \beta_{c} /\left(\beta_{a}+\beta_{c}\right)$ in Eq. 2 is fairly insensitive to small variations in values of $\beta_{a}$ and $\beta_{c}$.

On the other hand, the linear plots of $E$ against $i$ for cathodic polarization gave relatively good straight lines for all the alloys under all conditions. A representative plot is show in Fig. 12 for Hastelloy $\mathrm{C}$.

The most difficult measurement to obtain was the steady state corrosion potential, $\mathrm{E}_{\text {corr }}$. The time required for the sample electrodes to reach a value of $E_{\text {corr }}$ stable enough to enable polarization measurements to be made (less than a few millivolts change in an hour) was at least 15 to 20 hours after they were immersed in the seawater. In addition, after a polarization run had been completed and the power leads had been disconnected, the electrode would not return to the potential it had prior to being polarized, but would instead stabilize at a new potential which was less negative with respect to the S.C.E. The values of $E_{\text {corr }}$ reported are those obtained before polarization. The "initial" values of $\mathrm{E}_{\text {corr }}$ in deaerated unstirred seawater were $-0.219 \mathrm{~V},-0.155 \mathrm{~V}$, and $-0.132 \mathrm{~V}$ for Hastelloy $\mathrm{C}$, Hastelloy $\mathrm{N}$ and Haynes 25, respectively. The corresponding values in aerated seawater were $-0.168 \mathrm{~V},-0.125 \mathrm{~V}$, and $-0.052 \mathrm{~V}$.

In deaerated seawater solutions, stirring had little effect on $\mathrm{E}_{\text {corr }}$ for Haynes 25 and Hastelloy $\mathrm{N}$. For Hastelloy C, $\mathrm{E}_{\text {corr }}$ became approximately 50 millivolts less negative than without solution stirring. For aerated seawater $E_{\text {corr }}$ for all three alloys became approximately 50 millivolts less negative with solution stirring.

Table 2 summarizes the polarization data and presents the values of the corrosion rates, expressed in mils per year (mpy), for each of the alloys. $i_{\text {corr }}$ was converted to mil per year using Faraday's Law 


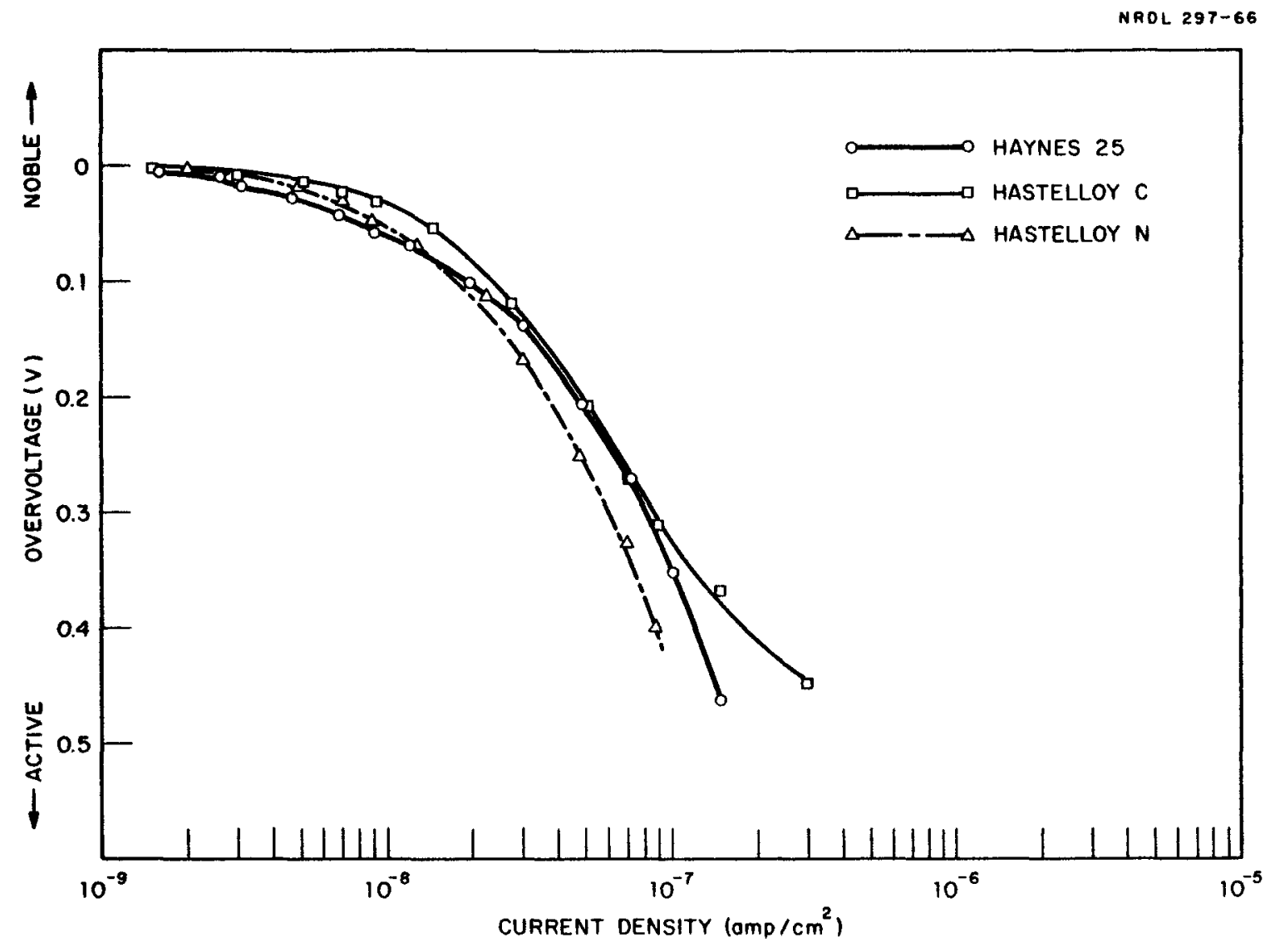

Fig. 4 Galvanostatic cathodic polarization curves for Haynes 25 , Hastelloy $\mathrm{C}$ and Hastelloy $\mathrm{N}$ in deaerated, stirred seawater. 


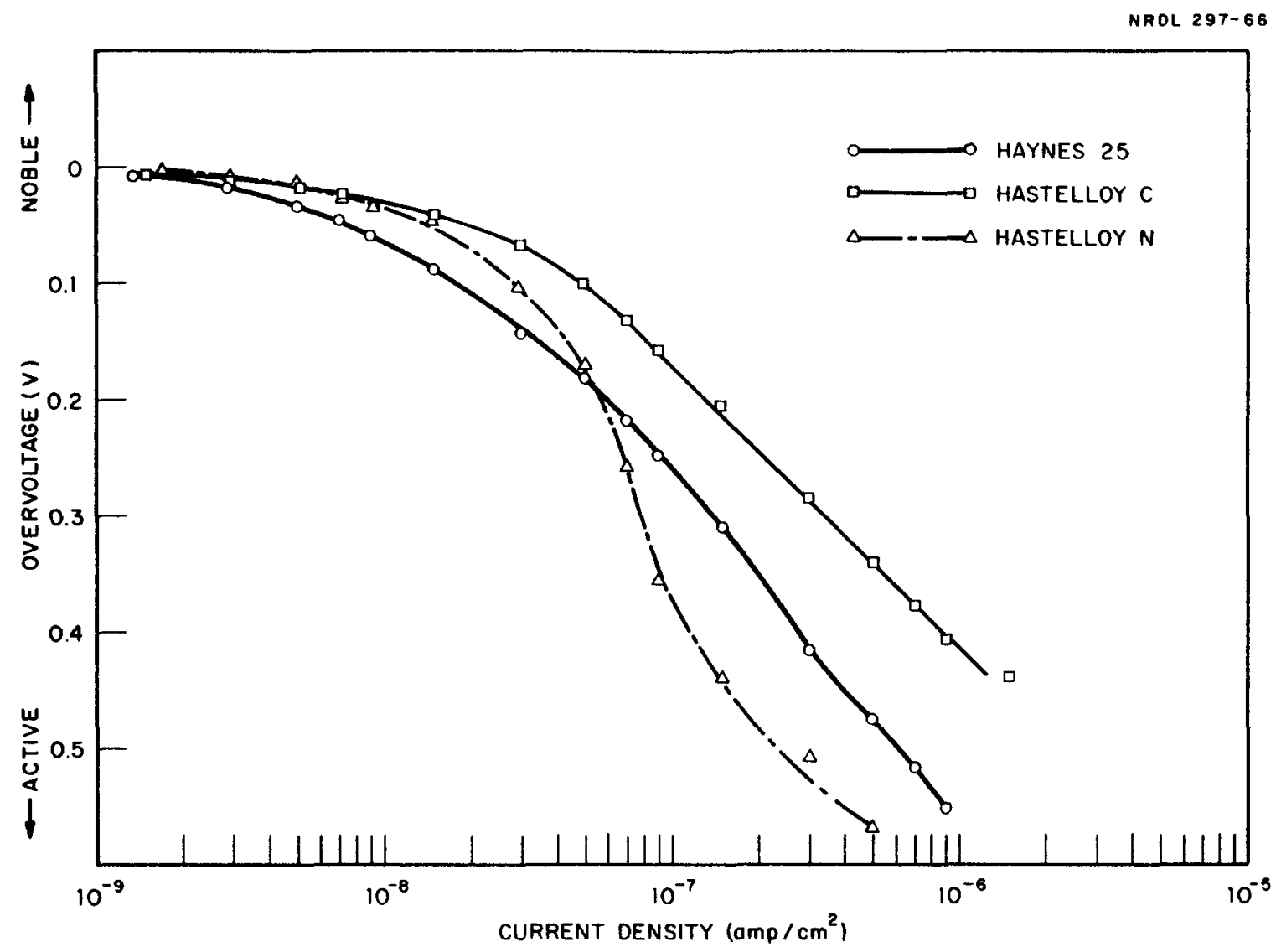

Fig. 5 Galvanostatic cathodic polarization curves for Haynes 25, Hastelloy $\mathrm{C}$ and Hastelloy $\mathrm{N}$ in deaerated, unstirred seawater. 


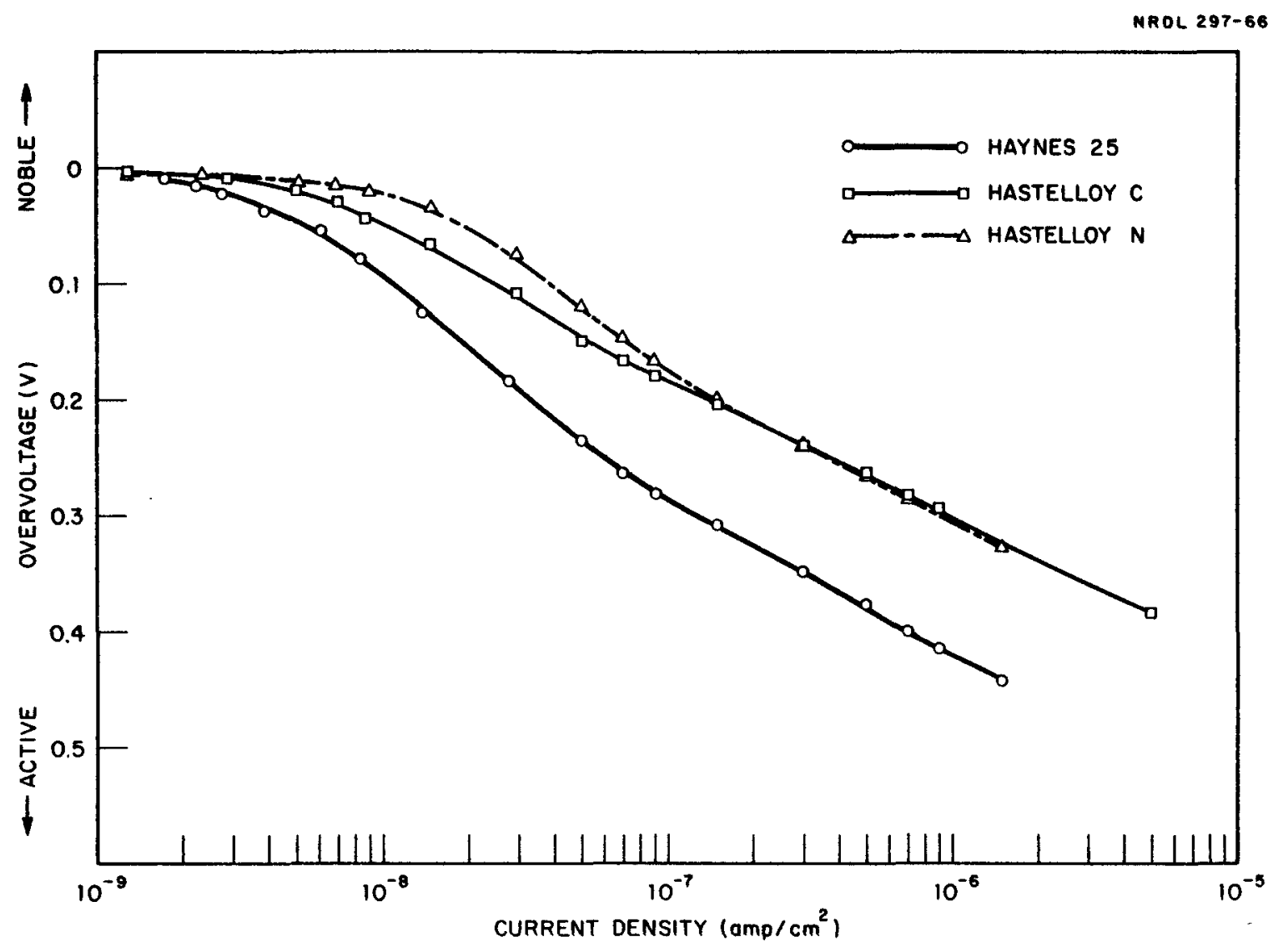

Fig. 6 Galvanostatic cathodic polarization curves for Haynes 25, Hastelloy $\mathrm{C}$ and Hastelloy $\mathrm{N}$ aerated, stirred seawater. 
NRDL 297-66

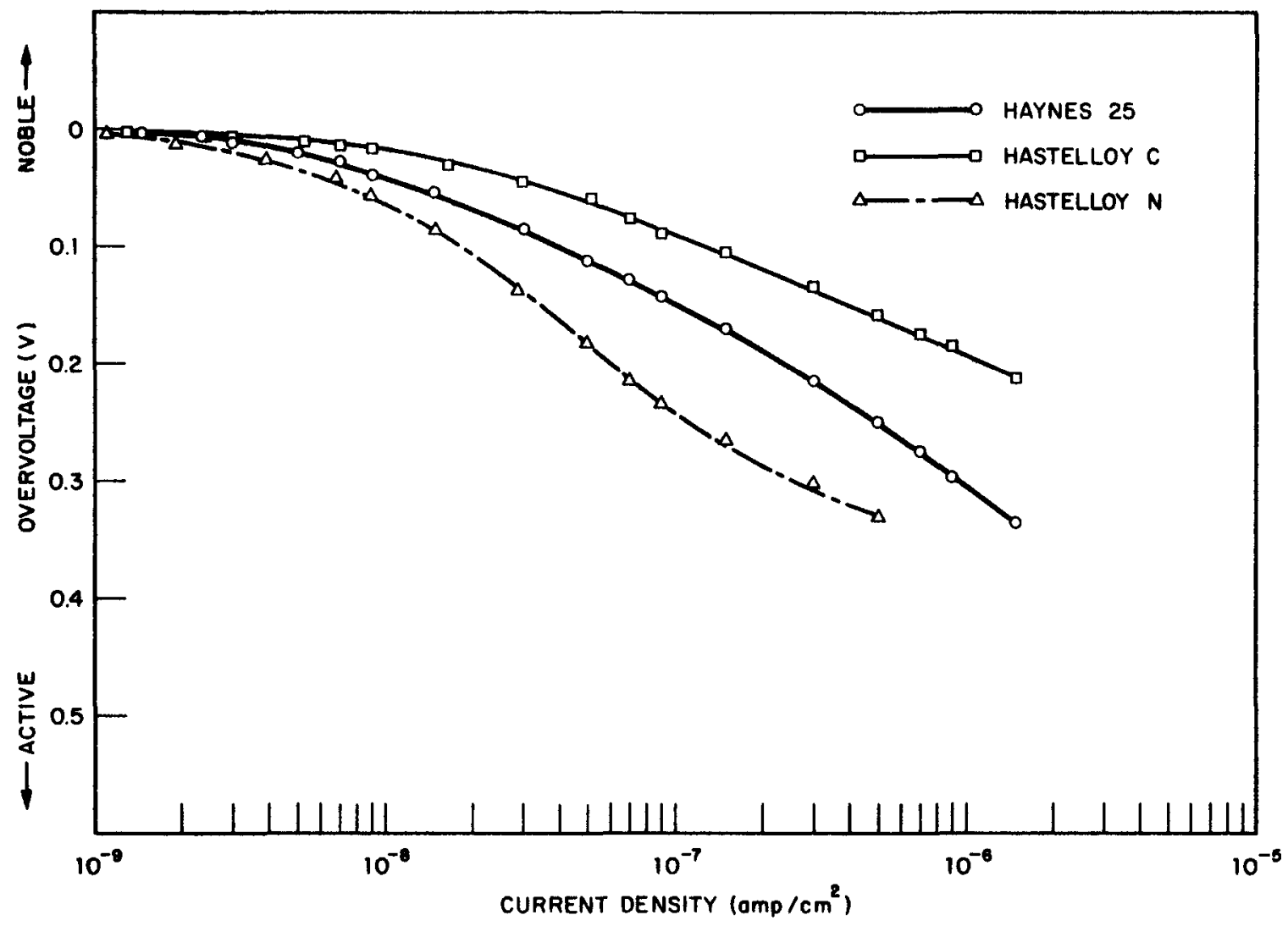

Fig. 7 Galvanostatic cathodic polarization curves for Haynes 25, Hastelloy $\mathrm{C}$ and Hastelloy $\mathrm{N}$ in aerated, unstirred seawater. 
NRDL 297-66

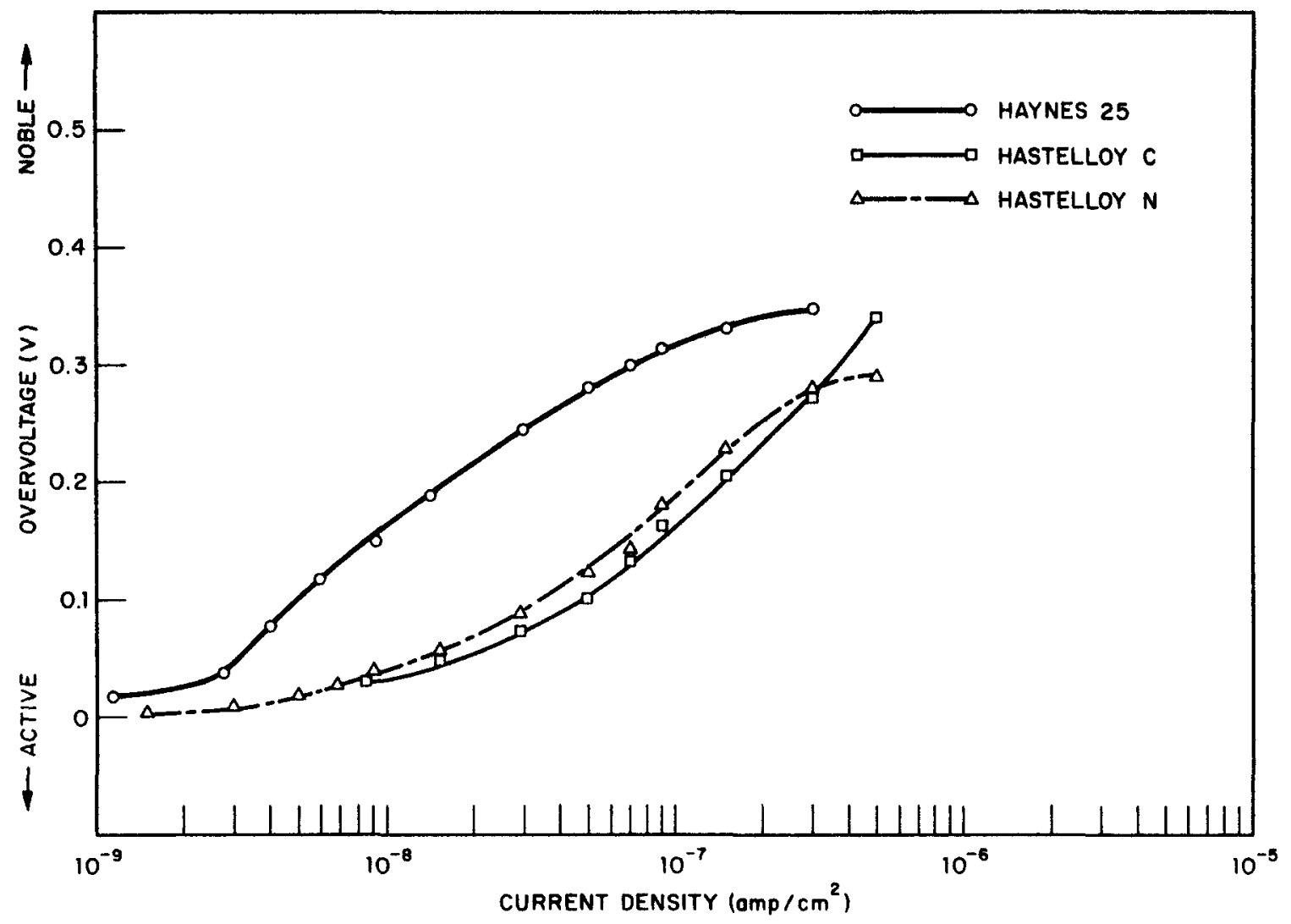

Fig. 8 Galvanostatic anodic polarization curves for Haynes 25, Hastelloy $\mathrm{C}$ and Hastelloy $\mathrm{N}$ in deaerated, stirred seawater. 


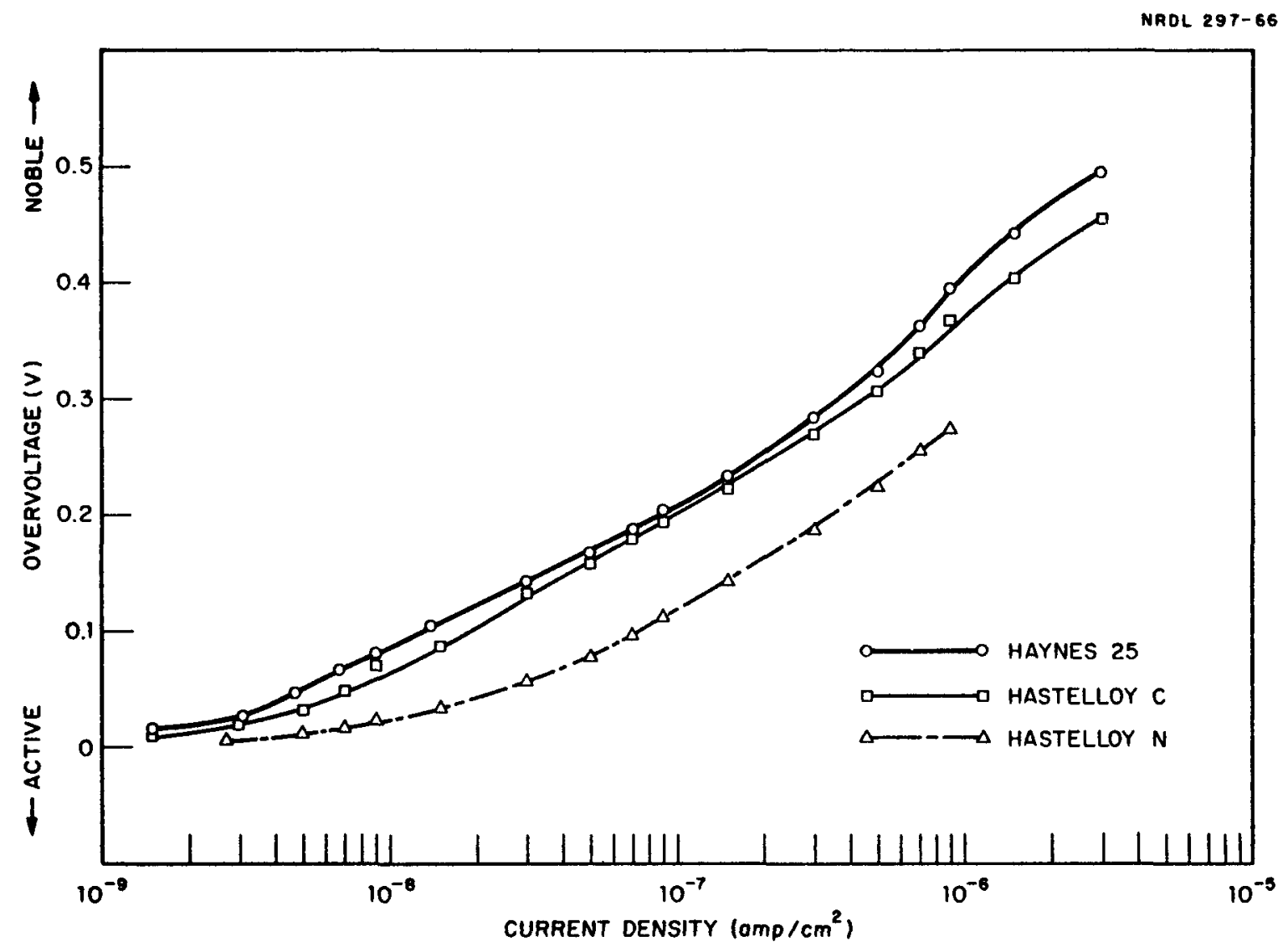

Fig. 9 Gelvanostatic anodic polarization curves for Haynes 25, Hastelloy $\mathrm{C}$ and Hastelloy $\mathrm{N}$ in deaerated, unstirred seawater. 


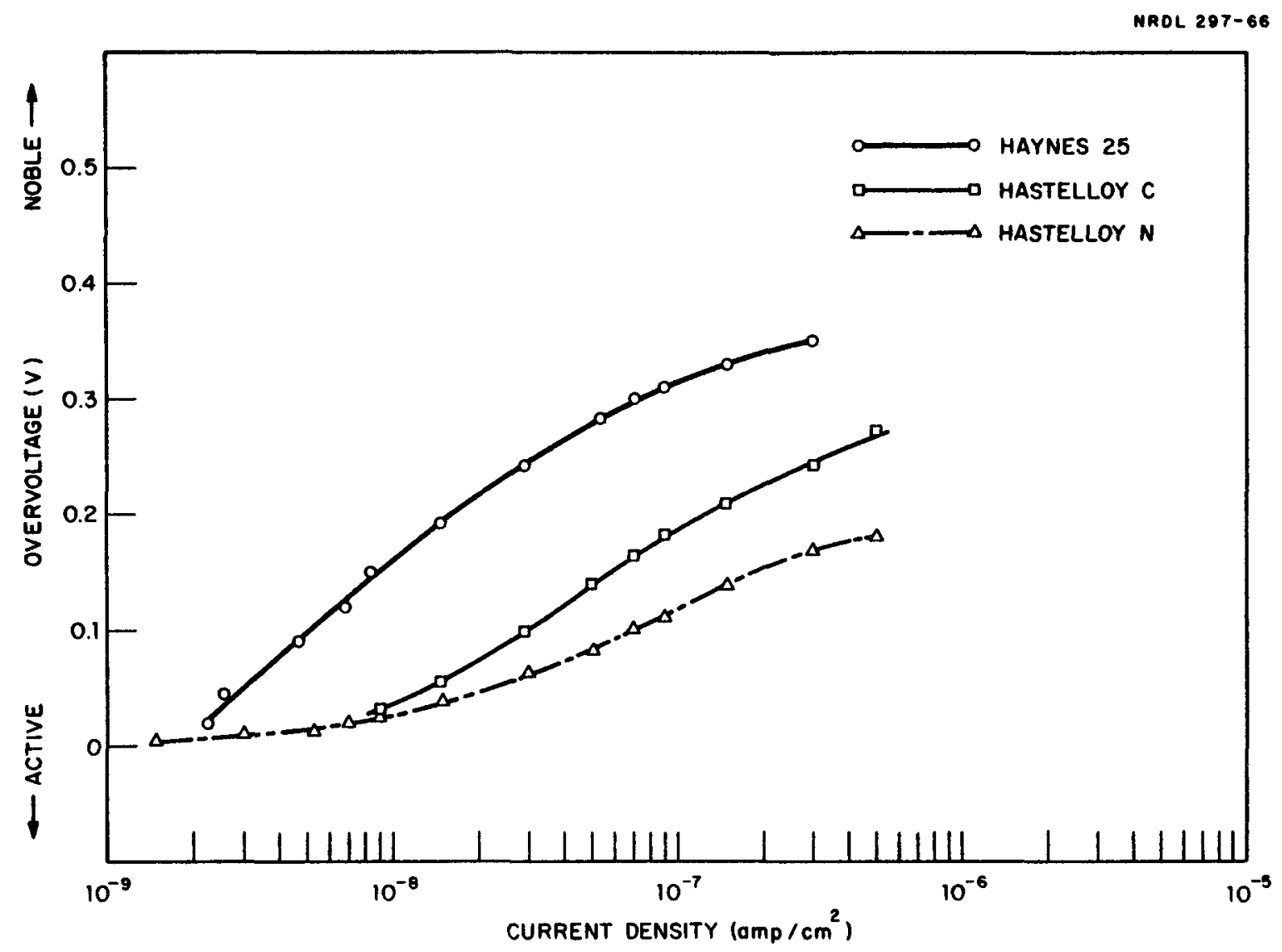

Fig. 10 Galvanostatic anodic polarization curves for Haynes 25, Hastelloy $\mathrm{C}$ and Hastelloy $\mathrm{N}$ in aerated, stirred seawater. 


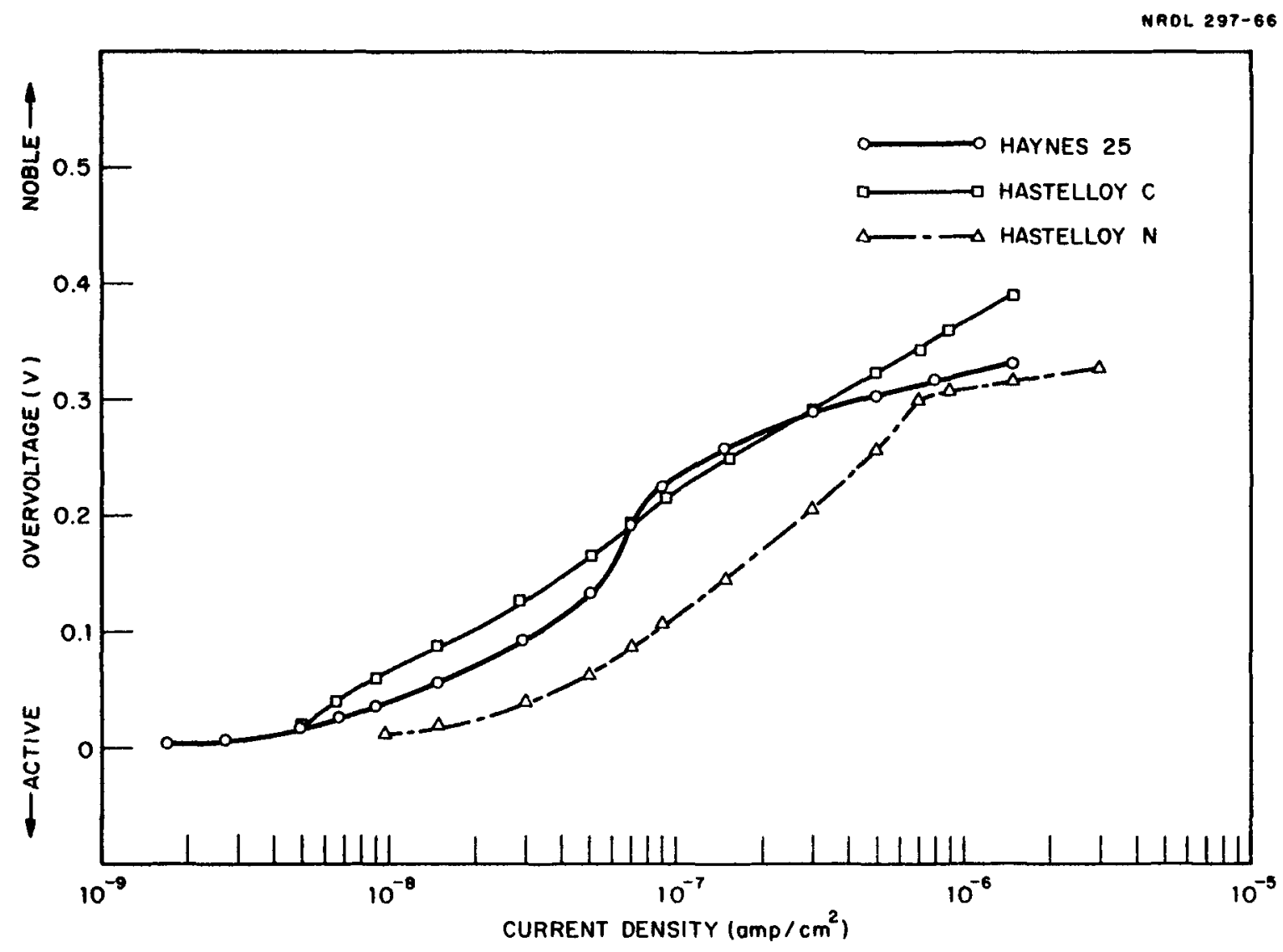

Fig. 11 Galvanostatic anodic polarization curves for Haynes 25, Hastelloy $\mathrm{C}$ and Hastelloy $\mathrm{N}$ in aerated, unstirred seawater. 


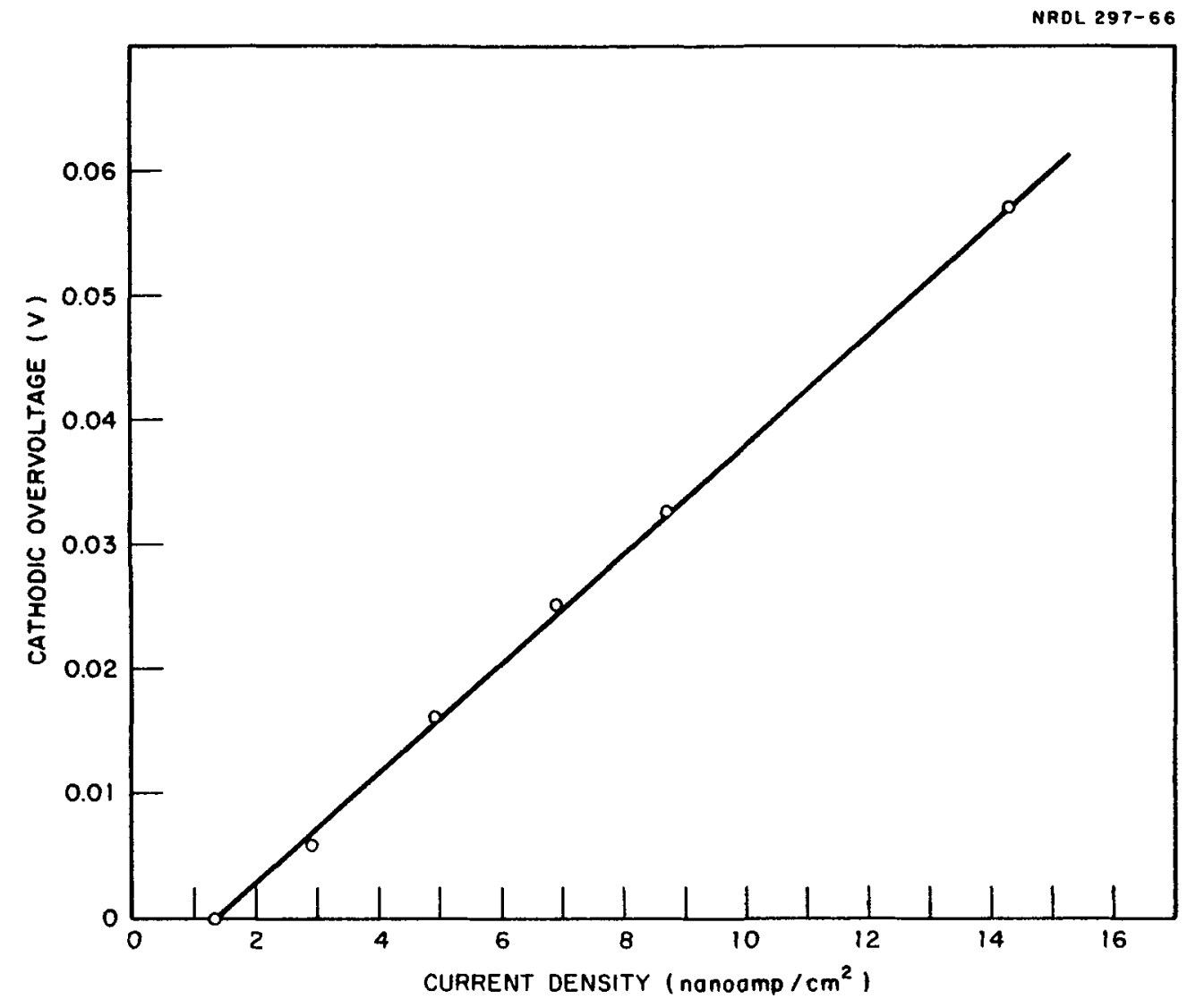

Fig. 12 Linear plot of cathodic overvoltage vs. current density for Hastelloy $\mathrm{C}$ in aerated, stirred seawater. 
TABLE 2

Summary of Electrochemical Data

\begin{tabular}{|c|c|c|c|c|c|}
\hline Conditions* & $\begin{array}{l}\beta_{c} \\
(v)\end{array}$ & $\begin{array}{c}\mathrm{B}_{\mathrm{a}} \\
(\mathrm{v})\end{array}$ & $\left(v / \mu\right.$ amp $\left./ \mathrm{cm}^{2}\right)$ & $\left(\begin{array}{l}i_{\operatorname{corr}} \\
\times 10^{-2}\end{array}\right.$ & $\begin{array}{l}\text { Corrosion Rate } \\
\text { (mpy) } \\
\times 10^{-2}\end{array}$ \\
\hline \multicolumn{6}{|c|}{ Hastelloy C } \\
\hline A, NS & .110 & .155 & 2.15 & 1.3 & 2.7 \\
\hline$A, S$ & .115 & .171 & 4.45 & .70 & 1.4 \\
\hline $\mathrm{D}, \mathrm{S}$ & .376 & .223 & 4.07 & 1.5 & 3.1 \\
\hline$D$, NS & .250 & .145 & 2.58 & 1.6 & 3.3 \\
\hline$D, N S$ & .332 & .235 & 6.80 & .88 & 1.8 \\
\hline $\mathrm{D}, \mathrm{NS}$ & .325 & .230 & 4.55 & 1.2 & 2.5 \\
\hline \multicolumn{4}{|c|}{ (Ave. for $\mathrm{D}, \mathrm{NS}$ ) } & $(1.2 \pm .4)$ & $(2.5 \pm .8)$ \\
\hline \multicolumn{6}{|c|}{ Hastelloy N } \\
\hline A, NS & .183 & .207 & 7.00 & .60 & 1.4 \\
\hline$A, S$ & .130 & .113 & 2.25 & 1.2 & 2.9 \\
\hline$D, s$ & .585 & .231 & 4.37 & 1.7 & 4.1 \\
\hline$D$, NS & .600 & .162 & 4.10 & 1.4 & 3.4 \\
\hline \multicolumn{6}{|c|}{ Haynes 25} \\
\hline$A$, NS & .132 & .352 & 5.60 & .75 & 1.4 \\
\hline$A, S$ & .135 & .205 & 10.5 & .34 & .64 \\
\hline $\mathrm{D}, \mathrm{S}$ & .680 & .180 & 6.2 & .99 & 1.9 \\
\hline$D$, NS & .300 & .120 & 6.6 & .56 & 1.1 \\
\hline
\end{tabular}

${ }^{*} A, N S=$ aerated, no stirring; $A, S=$ aerated, stirring; $D$, NS = deaerated, no stirring; $D, S=$ deaerated, stirring. 
and the assumption that the equivalent weights of the alloys are half their molecular weights (since bivalent ions would be expected from the major components). Included in Table 2 are the results of three runs, using Hastelloy $C$ in unstirred deaerated seawater, made to obtain a measure of reproducibility.

The results shown in Table 2 indicate that within the experimental error, there is no significant effect of aeration and solution stirring on the corrosion rates of the alloys. The average value of the corrosion rate for all the stirred solutions is $(2.3+1.0) \times 10^{-2} \mathrm{mpy}^{*}$ and for the nonstirred solutions is $(2.1 \pm 0.7) \times 1 \overline{0}-2$ mpy. The average value of the corrosion rate for all the aerated solutions is $(1.7+0.6) \times 10^{-2}$ mpy and for the deaerated solutions is $(2.7 \pm 1.0) \times 10^{-2} \mathrm{mp} \bar{y}$.

The averaged results for the three different alloys were: Hastelloy C, $(2.4+0.8) \times 10^{-2} \mathrm{mpy}$; Hastelloy $\mathrm{N},(3.0 \pm 1.2) \times 10^{-2} \mathrm{mpy}$; and Haynes $2 \overline{5},(1.2 \pm 0.4) \times 10^{-2} \mathrm{mpy}$.

The yalue for Hastelloy $C$ compares well with a literature value of
$10^{-2}$ mpy.
No literature values could be found for the other two alloys.

As mentioned above, values of $E_{\text {corr }}$ were difficult to obtain. The difference in the steady state potential before and after polarization varied from about 20 millivolts to as much as 150 millivolts. This observation, and the consistency of the corrosion rates shown in Table 2 , indicate that the corrosion rate is essentially independent of $E$ corr; at least within the range of variation of $\mathrm{E}_{\text {corr }}$ observed here.

CONCLUDING REMARKS

Since the results presented here were obtained under laboratory conditions it is not intended that they be extrapolated to an actual ocean environment. Rather, these results serve to provide a baseline to which results of future studies, more realistic in nature, can be compared. The results presented here are based on the assumption that the corrosion is uniform. Pitting or localized corrosion would be undetected by this method.

* The value of the percentage standard deviation for each value of the corrosion rate is assumed to be the same as the measured value determined for the triplicate deaerated, nonstirred solution of Hastelloy C (Table 2). 
Perhaps of more importance, these results show the feasibility of using electrochemical techniques to provide indications of the corrosion behavior of container alloys under various conditions. These conditions Include use of thermally shocked specimens (to simulate reentry heating and subsequent quenching in the ocean) and use of galvanically coupled specimens of the container alloy with other metal components of the container. The results obtained from these studies will provide an Indication of what may be expected from long-term ocean exposure studies. 
REFERENCES

1. P. E. Zigman, et al., "Radioactivity Release From Radionuclide Power Sources. I. Release From Strontium Titanate to Seawater", U.S. Naval Radiological Defense Laboratory, USNRDL-TR-745, 9 April 1964.

2. J. L. Mackin and P. E. Zigman, "Radionuclide Release From AeroSpace Nuclear Reactor Fuels. I. Safety Analysis of Pulsed Neutron Irradiation of Dry Fuel", U.S. Naval Radiological Defense Laboratory, USNRDL-TR-669, 8 August 1963.

3. J. L. Mackin, L. W. Weisbecker and P. E. Zigman, "Radionuclide Release From Aero-Space Nuclear Reactor Fuels. II. Phase One: Pulsed Neutron Irradiation of Dry Fuel", U.S. Naval Radiological Defense Laboratory, USNRDI-TR-811, 18 January 1965.

4. I. W. Weisbecker, H. I. Cordova, "Radionuclide Release From AeroSpace Nuclear Reactor Fuels. III. Phase One: Temperature Measurement of Fuel Under Pulsed Neutron Irradiation. U.S. Naval Radiological Defense Laboratory, USNRDI-TR-1006, 17 December 1965.

5. M. Stern and A. L. Geary, "Electrochemical Polarization. A Theoretical Analysis of the Shape of Polarization Curves", J. Electrochem. Soc. 104: 56 (1957).

6. M. Stern, "A Method for Determining Corrosion Rates From Linear Polarization Data", Corrosion 14:440 (1958).

7. H. A. Goya, et al, "A Method for the Collection, Storage and Monitoring Analysis of Natural Seawater", U.S. Naval Radiological Defense Laboratory, USNRDI-TR-637, 27 February 1963.

8. E. D. Weisert, "Hastelloy C", Chem. Eng. 59:297 (1952). 
INITIAL DISTRIBUTION

Copies

$\underline{\text { NAVY }}$

1 Chief of Naval Material (MAT 0331)

1 Chief of Naval Material (MAT 3241)

2 Commander, Naval Ship Systems Command (SHIPS 2021)

1 Commander, Naval. Ship Systems Command (SHIPS 03541)

1 Commander, Naval Air Systems Command (AIR 03)

1 Chief of Naval Operations (Op-OTT)

1 Chief of Naval Operations (Op-75)

1 Dir., Naval Research Laboratory

3 CO, Office of Naval Research, Branch Office, London

1 Supt., Naval Postgraduate School, Monterey

1 Commander, Naval Facilities Engineering Command (Code 042)

ARMY

1 Chief of Research and Development (Atomic Office)

1 CG, Army Materiel Command (AMCRD-DE-NE)

1 Commandant, Chemical Center and School

1 Commander, Nuclear Defense Laboratory

1 CO, Engineer Research and Development Laboratory

1 USACDC Institute of Nuclear Studies

AIR FORCE

1 Dir., USAF Project RAND

1 CG, Air Force Weapons Laboratory, Kirtland AFB (WLRB)

1 Dir., Air University Library, Maxwell AFB

1 Hq., Air Force Systems Command (SCIZN) (Nuclear Safety Branch)

1 Dir., Nuclear Safety (AFINS), Kirtland AFB (D. C. Jameson)

OTHER DOD ACTIVITIES

3 Dir., Defense Atomic Support Agency

1 Commander, FC/DASA, Sandia Base (FCDV)

20 Defense Documentation Center 
AEC ACTIVITIES AND OTHERS

Atomic Energy Commission, Washington

Atomic Energy Commission, Dir. of Res. (Dr. Pierce)

Atomic Energy Commission, Space Electric Power Office, Germantown (G. P. Dix)

Atomic Energy Commission, Space Nuclear Propulsion Office, Germantown (R. Decker)

Atomic Energy Commission, Isotopic Power System Branch

(B. Rock, R. Carpenter)

Atomic Energy Commission, Div. of Isotope Development (W. Kern)

Atomic Energy Commission, Div. of Reactor Development and

Technology (W. Regan, S. Seiken)

Atomic Energy Commission, Div. of Biology and Medicine

(A. Joseph)

Atomic Energy Commission, Reactor Div. of Safety Standards (J. J. Dinunno)

Atomic Energy Commission, New York Operations Office (J. Harley) NUS Corp. (M. Goldman)

Pacific N. W. Laboratory, Richland (R. Thompson, H. Kornberg) University of California, Berkeley (V. Schrock, I. Cornet) G. E. Co., Valley Forge Space Technology Center (F. Witt, C. Gammertsfelder)

G. E. Co., Nuclear Materials and Propulsion Operation, Cincinnati (W. Briskin)

Monsanto Research Corp., Miamisburg (G. Grove, J. Kahle, D. Kelly, F. Lonadier, C. Henderson)

Stanford Research Institute (L. Weisbecker)

Aerospace Nuclear Safety, Sandia Corp, Albuquerque (V. Blake, E. Hansen)

National Aeronautics and Space Admin. (Code RNS) (T. Kerr)

National Aeronautics and Space Admin., Goddard Space Flight

Center, Greenbelt, Maryland (C. Baxter, A. W. Fihelly)

National Aeronautics and Space Admin., George C. Marshall

Space Flight Center, Huntsville, Alabama (W. Y. Jordan)

National Aeronautics and Space Admin., Ames Research Center, Moffett Field, California (G. Goodwin)

Boston College (I. J. Russell)

Dayton Area Office, Mound Laboratory, Miamisburg (T. Gore)

Atomics International, Canoga Park, Calif. (R. L. Detterman)

Douglas Aircraft Co., Inc., Missile and Space Systems Div., Santa Monica (S. Gromich)

Martin Co., Nuclear Div., Middle River, Maryland (D. G. Harvey)

Minnesota Mining and Manufacturing Co. (R. Marchant)

Union Carbide Corp., Nuclear Div., Oak Ridge (E. Lamb)

Radd Associates, Palo Alto (H. Radd) 
1 National Bureau of Standards (Library)

15 Division of Technical Information Extension, Oak Ridge

USNRDL

45 Technical Information Division

DISTRIBUTION DATE: 19 JUIy 1966 


\begin{tabular}{|c|c|c|c|}
\hline $\begin{array}{l}\text { Naval Radiological Defense Laboratory } \\
\text { USNRDL-TR-1036 } \\
\text { ILECTROCHDITCAL CORROSION STUDIES OF } \\
\text { SNAP CONTAINER MATERIALS, by D. A. Kubose } \\
\text { and H. I. Cordova } 7 \text { June 1966 } 33 \text { p. } \\
\text { tables illus. } 8 \text { refs. UNCLASSIF IED } \\
\text { Corrosion rates of Haynes 25, Hastelloy } \\
\text { C and Hastelloy } \mathrm{N} \text { in natural seawater were } \\
\text { determined by galvanostatic polarization } \\
\text { techniques. Values of approximately I0-2 } \\
\text { mils per year were obtained for each of the } \\
\text { alloys. No significant effect of aeration } \\
\text { and solution stirring on the } \\
\text { corrosion rates was observed. }\end{array}$ & $\begin{array}{l}\text { 1. Corrosion } \\
\text { 2. Seawater } \\
\text { 3. Alloys } \\
\text { 4. Polarographic } \\
\text { analysis } \\
\text { I. Kubose, D. A. } \\
\text { II. Cordova, H. I. } \\
\text { III. Title } \\
\text { UNCLASSIFIED }\end{array}$ & 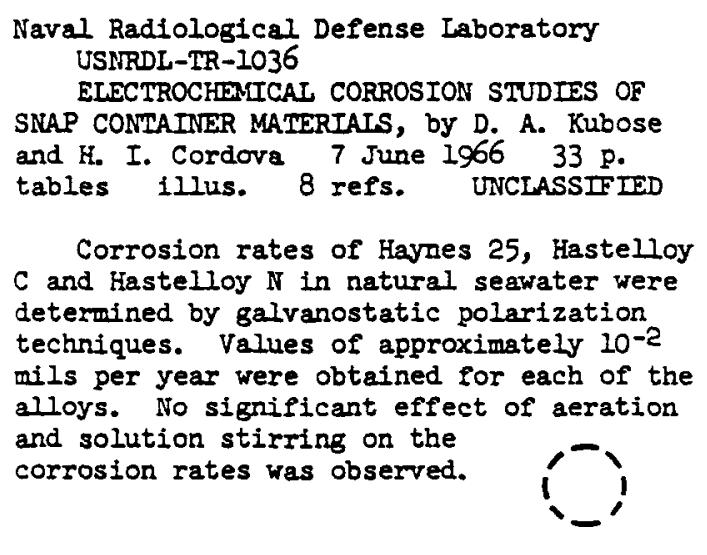 & $\begin{array}{ll}\text { 1. } & \text { Corrosion } \\
\text { 2. Seawater } \\
\text { 3. Alloys } \\
\text { 4. Polarographic } \\
\text { analysis } \\
\text { I. Kubose, D. A. } \\
\text { II. Cordova, H. I. } \\
\text { III. Title } \\
\\
\text { UWCLASSIFIED }\end{array}$ \\
\hline & UNCLASSIFIED & & UNCLASSIFIED \\
\hline
\end{tabular}


Naval Radiological Defense Laboratory USNRDL-TR-1036

ELECTROCHEMICAL CORROSION STUDIES OF SNAP CONTAINER MATERIALS, bY D. A. Kubose and H. I. Cordova 7 June $196633 \mathrm{p}$. tables illus. 8 refs. UNCLASSIFIED

Corrosion rates of Haynes 25, Hastelloy $\mathrm{C}$ and Hastelloy $\mathrm{N}$ in natural seawater were determined by galvanostatic polarization techniques. Values of approximately $10^{-2}$ mils per year were obtained for each of the alloys. No significant effect of aeration and solution stirring on the corrosion rates was observed.
1. Corrosion

2. Seawater

3. Alloys

4. Polarographic analysis

I. Kubose, D. A. II. Cordova, H. I. III. Title
Naval Radiological Defense Laboratory USNRDL-TR - 1036

ELECTROCHEMICAL CORROSION STUDIES OF SNAP CONTAINER MATERIALS, by D. A. Kubose and H. I. Cordova 7 June $196633 \mathrm{p}$.
tables

$$
\text { ilius. } 3 \text { refs. INCLASSIFIED }
$$

Corrosion rates of havnes 25, hastelloy $C$ and Hastelloy $N$ in natural seawater were determined by galvanostatic polarization techniques. Vaiues of approximately 10-2 mils per year were obtained for each of the alloys. No significant effect of aeration and solution stirring on the corrosion rates was observed.
1. Corrosion

2. Seawater

3. Alloys

4. Polarographic analysis

I. Kubose, D. A. II. Cordova, H. I. III. Title

\section{UNCLASSIFIED}

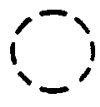

UNCLASSIFIED

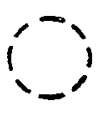




\section{UNCLASSIFIED}

Security Classification

\section{DOCUMENT CONTROL DATA - R\&D}

(Security clasaification of title, body of abstract and indexing annotation must be entered when the overall report is classified) 1. ORIGINATIN G ACTIVITY (Corporato author)

U. S. Naval Radiological Defense Laboratory

San Francisco, California 94135

2a. REPORT SECURITY CLASSIFICATION UNCLASSIFIED

2b. GROUP

3. REPORT TITLE

ELECTROCHEMICAL CORROSION STUDIES OF SNAP CONTAINER MATERIALS

4. DESCRIPTIVE NOTES (Type of report and inclusive dates)

5. AUTHOR(S) (Laat name, first name, initial)

Kubose, Don A。

Cordova, Herman $I_{\text {。 }}$

6. REPO RT DATE

19 July 1966

7a. TOTAL NO. OF PAGES

7b. NO. OF REFS

8a. CONTRACT OR GRANT NO.

AEC Contract No. AT $(49-5)-2084$.

b. PROJECT NO.

33

8

9. ORIGINATOR'S REPORT NUMEER(S)

USNRDL-TR-1036

c.

9b. OTHER REPORT NO(S) (Any other numbers that may bo aseigned

d.

10. AVA IL ABILITY/LIMITATION NOTICES

Distribution of this document is unlimited.

11. SUPPL EMENTARY NOTES

12. SPONSORING MILITARY ACTIVITY

Atomic Energy Commission

Washington, D. C. 20545

13. ABSTRACT

Corrosion rates of Haynes 25, Hastelloy $\mathrm{C}$ and Hastelloy $\mathrm{N}$ in natural seawater were determined by galvanostatic polarization techniques. Values of approximately $10^{-2}$ mils per year were obtained for each of the alloys. No significant effect of aeration and solution stirring on the corrosion rates was observed. 


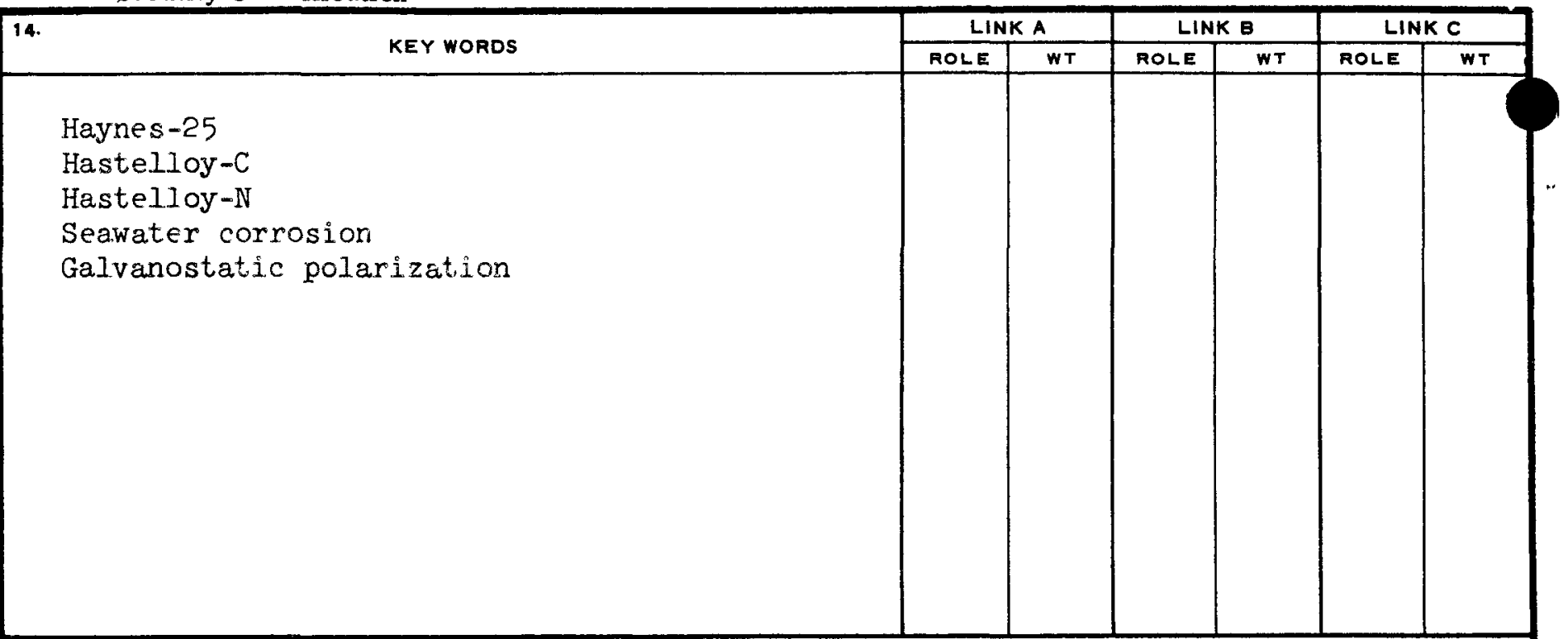

\section{INSTRUCTIONS}

1. ORIGINATING ACTIVITY: Enter the name and address of the contractor, subcontractor, grantee, Department of Defense activity or other organization (corporate author) issuing the report.

2a. REPORT SECURTY CLASSIFICATION: Enter the overall security classification of the report. Indicate whether "Restricted Data" is included. Marking is to be in accordance with appropriate security regulations.

2b. GROUP: Automatic downgrading is specified in DoD Directive 5200.10 and Armed Forces Industrial Manual. Enter the group number. Also, when applicable, show that optional markings have been us ed for Group 3 and Group 4 as authorized.

3. REPORT TITLE: Enter the complete report title in all capital letters. Titles in all cases should be unclassified. If a meaningful title cannot be selected without classification, show title classification in all capitals in parenthesis immediately following the title.

4. DESCRIPTIVE NOTES: If appropriate, enter the type of report, e.g., interim, progress, summary, annual, or final. Give the inclusive dates when a specific reporting period is covered.

5. AUTHOR(S): Enter the name(s) of author(s) as shown on or in the report. Enter last name, first name, middle initial. If military, show rank and branch of service. The name of the principal author is an absolute minimum requirement.

6. REPORT DATE: Enter the date of the report as day, month, year; or month, year. If more than one date appears on the report, use date of publication.

7a. TOTAL NUMBER OF PAGES: The total page count should follow normal pagination procedures, i. e., enter the number of pages containing information.

7b. NUMBER OF REF ERENCES: Enter the total number of references cited in the report.

8a. CONTRACT OR GRANT NUMBER: If appropriate, enter the applicable number of the contract or grant under which the report was written.

$8 b, 8 c, 8$ 8d. PROJECT NUMBER: Enter the appropriate military department identification, such as project number, subproject number, system numbers, task number, etc.

9a. ORIGINATOR'S REPORT NUMBER(S): Enter the official report number by which the document will be identified and controlled by the originating activity. This number must be unique to this report.

9b. OTHER REPORT NUMBER(S): If the report has been assigned any other report numbers (either by the originator or by the sponsor), also enter this number(s).

10. AVAILABILITY/LIMITATION NOTICES: Enter any limitations on further dissemination of the report, other than those imposed by security classification, using standard statements such as:

(1) "Qualified requesters may obtain copies of this report from DDC."

(2) "Foreign announcement and dissemination of this report by DDC is not authorized."

(3) "U. S. Government agencies may obtain copies of this report directly from DDC. Other qualified DDC users shall request through

(4) "U. S. military agencies may obtain copies of this report directly from DDC. Other qualified users shall request through

5) "All distribution of this report is controlled. Qualified DDC users shall request through ."

If the report has been furnished to the Office of Technical Services, Department of Commerce, for sale to the public, indicate this fact and enter the price, if known.

11. SUPPLEMENTARY NOTES: Use for additional explanatory notes.

12. SPONSORING MILITARY ACTIVITY: Enter the name of the departmental project office or laboratory sponsoring (paying for) the research and development. Include address.

13. ABSTRACT: Enter an abstract giving a brief and factual summary of the document indicative of the report, even though it may also appear elsewhere in the body of the technical report. If additional space is required, a continuation sheet shall be attached.

It is highly desirable that the abstract of classified reports be unclassified. Each paragraph of the abstract shall end with an indication of the military security classification of the information in the paragraph, represented as (TS), (S), (C), or (U).

There is no limitation on the length of the abstract. However, the suggested length is from 150 to 225 words.

14. KEY WORDS: Key words are technically meaningful terms or short phrases that characterize a report and may be used as index entries for cataloging the report. Key words must be selected so that no security classification is required. Identifiers, such as equipment model designation, trade name, military project code name, geographic location, may be used as key words but will be followed by an indication of technical context. The assignment of links, rales, and weights is optional. 